Portland State University

PDXScholar

1976

\title{
The Impact of SSI on the Social Security Administration: an Intraorganizational Study with Interorganizational Ramifications
}

Patricia A. Parker

Portland State University

Follow this and additional works at: https://pdxscholar.library.pdx.edu/open_access_etds

Part of the Social Work Commons

Let us know how access to this document benefits you.

Recommended Citation

Parker, Patricia A., "The Impact of SSI on the Social Security Administration: an Intraorganizational Study with Interorganizational Ramifications" (1976). Dissertations and Theses. Paper 1906.

https://doi.org/10.15760/etd.1905

This Thesis is brought to you for free and open access. It has been accepted for inclusion in Dissertations and Theses by an authorized administrator of PDXScholar. Please contact us if we can make this document more accessible: pdxscholar@pdx.edu. 


\section{THE IMPACT OF SSI ON THE \\ SOCIAL SECURITY ADMINISTRATION: \\ AN INTRAORGANIZATIONAL STUDY WITH \\ INTERORGANIZATIONAL RAMIFICATIONS}

by

PATRICIA A. PARKER

A practicum submitted in partial fulfillment of the requirements for the degree of

MASTER OF

SOCIAL WORK 
TABLE OF CONTENTS

PAGE

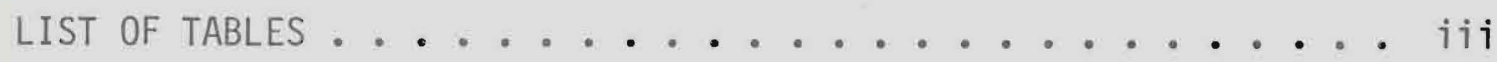
CHAPTER

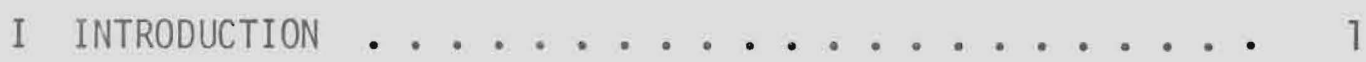

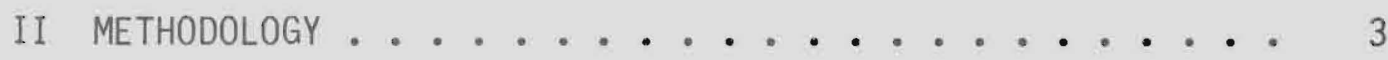

III THE SOCIAL SECURITY SYSTEM AND SSI $\ldots \ldots \ldots$

IV THE ORGANIZATIONAL CHANGE PROCESS ............ 18

V THE EVALUATION STAGE -- THE SOCIAL SECURITY

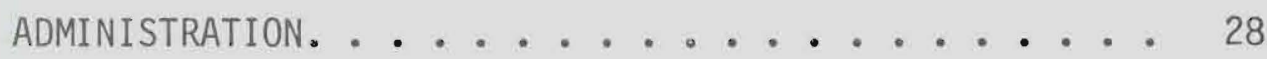

VI THE INITIATION STAGE -- THE SOCIAL SECURITY ADMINISTRATION ........................ 31

VII THE IMPLEMENTATION STAGE -- THE SOCIAL SECURITY ADMINISTRATION ...................... 37

VIII THE ROUTINIZATION STAGE -- THE SOCIAL SECURITY ADMINISTRATION .................... 46

IX SUMMARY AND CONCLUSIONS .................. 58

BIBLIOGRAPHY ........................ 66

APPENDIX - THE SSI COMMUNITY SERVICE SYSTEM SURVEY INTERVIEW

AND FORMAT .......................... 71 


\section{LIST OF TABLES}

TABLE

PAGE

I Number of Social Security Administration

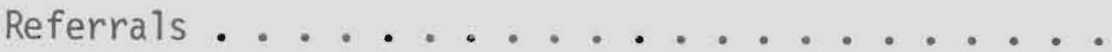

II Contacts with the Social Security Administration

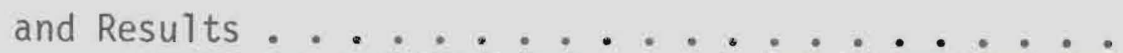




\section{CHAPTER I}

\section{INTRODUCTION}

In 1974 a revolutionary new income maintenance program was implemented in the United States. It was revolutionary in style because it provided a federalized income floor for the elderly, blind and disabled, previously provided for under various federal, state, and local welfare programs. The program was called Supplemental Security Income, or SSI.

The Social Security Administration, a long-standing institution in the financial community because of old age, survivors and disability insurance (OASDI) benefits, was chosen to administer SSI. SSI represented a new innovation for the Social Security Administration who had never before had to provide non-work-related benefits to indigents. In order to incorporate the SSI program, the Social Security Administration had to change its organizational goals and functions.

Organizational change is an increasingly important phenomenon to be researched today. This study examines the initiation of a new program, SSI, in the context of intraorganizational change. ${ }^{*}$ The basic hypothesis is that the implementation of a new program function within an existing organization causes the organization to undergo a process of change to incorporate the new program.

Due to the nature of the extent of change involved when the

* The concept of "intraorganizational change" as used here is defined as change within the focal, or particular, organization being studied. 
Social Security Administration undertook the Supplemental Security Income Program, it was hypothesized there would be a subsequent change in the interorganizational relationships of the Social Security Administration and the local community. This assumption was made because the new goal of the Social Security Administration relative to SSI was to provide information and referral services to an indigent population previously not serviced by Social Security.

This study attempts to examine the changes going on within the Social Security Administration because of the adoption of the SSI program and relate them to these four issues:

1. The extent and nature of the SSI program and the program change, specifically with regard to the elderly population.

2. The subsequent changes in interorganizational relationships and contacts called for during the implementation of SSI.

3. The development and success of information and referral services as part of the Social Security Administration's functioning.

4. The role of the Social Security Administration within the local community.

These issues will be examined within the context of the intraorganizational change process and will be reviewed again at the conclusion of the study. 


\section{CHAPTER II}

\section{METHODOLOGY}

This study was undertaken as a part of longitudinal research conducted at the Institute on Aging at Portland State University which investigated the impact of SSI on a low-income, elderly population.

There were three data sources used here:

1. a literature review;

2. the SSI impact study mentioned above; and

3. a community survey.

The literature reviewed covered these areas: the nature of the structure of the Social Security Administration; current policies and procedures of the Social Security Administration; the development and guidelines of the Supplemental Security Income Program; and organizational literature providing a framework for understanding organizational relations within and outside of an organization, in order to understand how an organization undergoes a process of change in program functioning.

The SSI Impact Study consisted of an intensive interview conducted in 1975 with 400 differentially impaired, urban elderly in the Portland, Oregon, area. Only a fraction of this data is used here, specifically questions with regard to the information and referral practices of the Social Security Administration. The questions are pertinent to the functioning of the Social Security Administration's overall program with regard to SSI. 
The sample was drawn from previous data used by the Institute on Aging. Basically the sample ranged in age from 65 to 98, with a mean age of 77. Seventy-five percent lived alone, and almost 60 percent had incomes below the national poverty 1ine. (Department of Labor, 1975) Many of these people were eligible for SSI, and 82 were in fact receiving SSI. Two hundred seventy-five were receiving Social Security and/or SSI and, therefore, were presumed to have had some contact with the Social Security Administration.

The third data source was a group of interviews with agency personnel. During Apri1 and May of 1975, 27 persons from 16 different agencies in the Portland metropolitan area were interviewed. The agencies represented a wide spectrum of new and old, large and small agencies, providing services ranging from residential care to medical, legal, recreational, financial, nutritional, and various social services for the Portland metropolitan area, and specifically the urban elderly. Respondents were chosen from administrative as well as direct service positions. In total, 15 administrators and 12 service persons were interviewed.

The interview format consisted of a series of questions designed to elicit information about the agency, the respondent's position within the agency, the respondent's knowledge about and personal experience with the Supplemental Security Income program, his perception of actual and ideal roles of the Social Security Administration within the service delivery system, and the nature and extent of any contact the agency has with the Social Security Administration. (See the Appendix for a copy of the interview format.) 
Thus, this research looks at three areas: literature relevant to provide a framework for the study; data from elderly individuals, many of whom were beneficiaries of payments from the Social Security Administration; and a community survey to assess how well integrated the SSI program was as measured by the knowledge agency personnel possessed about SSI and how well defined the Social Security Administration's role was in the local community. 


\section{CHAPTER III}

This chapter describes the development of the Social Security insurance system and the subsequent creation of the Supplemental Security Income (SSI) program. The historical review is designed to provide a background of the work-related insurance concept of Social Security benefits. The detailed discussion of SSI shows how SSI, in contrast, is based on an income criteria, likening it to previous welfare programs.

\section{The Social Security System}

Social Security, established in the 1935 "New Deal" package developed by President Franklin D. Roosevelt, was the first federal level action in the area of income maintenance. Social Security (or 01d Age Survivors and Disability Insurance) was a straight forward insurance plan for providing workers with income in their old age, and to care for their widows and dependent children should they die.

Financed by a tax on wages and payrolls, the money. is placed in a trust fund, which is used to cover current obligations. The concept of "work-related" insurance has always been connected with basic OASDI payments, and people think of their Social Security benefits as "earned."

The authors of the legislation foresaw the day when almost a11 workers and their dependents would be eligible for such benefits. In the interim, there would be a number of old, disabled, or widowed persons, some of whom would be caring for children, that would not be 
eligible for retirement benefits. Thus, interval programs were included in the program (01d Age Assistance; Aid to the Blind; Aid to Dependent Children; and finally, Aid to the Permanently and Totally Disabled, which was added in 1950).

In the original construction of the 1935 Social Security Act, a political movement for federal old-age pensions arose, and Roosevelt moved to head off a pension plan by creating Social Security. "The 01dAge Assistance provisions of the act provided in effect a pension for the aged destitute of the time, but the long-range principle was to be one of social insurance rather than of relief." (Moynihan, 1973:43)

The presumption of these categorical programs was that they would gradually decline and perhaps even disappear. This certainly seemed to be happening up to the mid-1960's. However, in the '60's this "withering away" assumption fell through (particularly in the area of AFDC) and we saw increasing rises in the welfare roles. These rises came at such a tremendous rate, politicians and the public alike began to see what had come to be known as "welfare dependency" as a crisis. "In the twelve months ending June 30, 1970, the number of Americans receiving public assistance rose to a record of 12.2 million, an increase of .. 20 percent, in a single year. The cost rose to $\$ 12.8$ billion. In over one-quarter of the states the rolls went up by one-third or more, Texas as well as Michigan, Maine along with Washington and Oregon; no part of the nation was unaffected." (Ibid. 34)

While all this furor was happening, it is important to note that these tremendous increases came primarily from the Aid to Families with Dependent Children category. In fact, from 1955 to 1970, the number of 
persons receiving 01d-Age Assistance declined in round figures from $2,540,000$ to $2,100,000$. The number receiving Aid to the Blind dropped from 100,000 to 81,000 . (Moynihan, 1973)

\section{Supplemental Security Income}

As the ' 60 's came to a close, the welfare crisis was of foremost concern in America. Richard Nixon's Family Assistance Plan was described as a radical approach to an income strategy. The plan was eventually defeated largely due to opposition revolving around the controversial AFIC program and providing welfare money to "non-workers" as a disincentive to the work ethic.

Only one element of the Family Assistance Plan was finally adopted; this program was entitled Supplemental Security Income, or SSI, and came in the 1972 amendments to the Social Security Act. SSI reiterated the original intent of the Social Security Act, to pick up those aged, blind and disabled persons who were destitute, and extend to them "social insurance", as it were, not "relief".

Public Law 92-603 established the SSI program and did away with the state welfare programs for aged, blind and disabled people. The major objective of SSI was to provide, through a federally administered program, positive assurance that the nation's aged, blind and disabled would be provided with a minimum income and to establish basic eligibility requirements and payment standards that are uniform nationally, unlike those under 1152 previously existing state, county, and local welfare programs of $01 \mathrm{~d}$ Aid Assistance (OAA), Aid to the Blind (AB), and Aid to the Permanentiy and Totally Disabled (APTD). 
Average Payments Under Previous State Ass istance Programs

"Under the public assistance programs existing before SSI began operations, the Federal Government provided grants-in-aid on a matching basis to each state administering its own program within the framework of conditions set down by the Social Security Act and Federal regulations. The states had wide latitude in determining who was eligible and the amount of assistance that eligible persons could receive. Each state defined its own minimum standard of living (known as a 'needs standard') against which an individual's income and resources were measured to determine whether financial need existed. Any individual with income below the State needs standard - and who met other specified requirements - was eligible for some ass istance". (Rigby, 1974:21) However, the State was not required to pay the full amount of the needs standard to a recipient with no income nor the difference between the standard and countable income. Although theoreticaliy a minimum standard was set, it was subject to legislative limitations on expenditures. Wide variations existed among states (and sometimes within states) in areas such as administration, eligibility requirements, assistance payment levels, and state and local government budgets for welfare. Nationwide averages in December of 1973 were about $\$ 83$ for those with OAA payments (although payments ranged from $\$ 56$ to $\$ 121$ monthly between states), $\$ 104$ for individuals receiving $A B$, and $\$ 112$ for those on APTD. Nationally, the assistance payment to aged couples averaged about 40 percent higher than that to individuals ( $\$ 116$ compared with \$83). (Ibid.) 
Payments Under SSI

Supplemental Security Income reflected a flat grant approach to meet the minimum needs of those eligible under the program. ${ }^{\star}$ Funded from the general tax revenue, and not Social Security trust funds, the SSI benefit was not intended to provide enough cash to meet al1 needs. For example, it was not intended to help meet medical care needs, but in some cases an individual's eligibility for other benefits, such as Medicaid, may depend on his or her being eligible for SSI. "Therefore, the value to the individual of eligibility for a partial SSI benefit of a few dollars may be far greater than the dollar value of the SSI benefit". (Center on Social Welfare Policy and Law, 1975:ii)

"As originally established, the monthly payment standard under the Federal SSI program was $\$ 130$ for an individual living in his own household with no other income and $\$ 195$ for a couple with both husband and wife el igible. Effective for January 1974 - the first month of SSI operations - these amounts were increased, however, to $\$ 140$ and $\$ 210$, respectively". (Kennedy, et a1, 1975:22)

\section{*Eligibility} must be:

In order to be eligible for benefits an individual (or couple)

1. aged 65 or over; blind or disabled under the Social Security Administration's criteria;

2. be in need of money for the basic necessities of food, clothing and sheiter;

3. have a limited amount of resources; and

4. be a U. S. citizen or be lawfully admitted for permanent residence. 
Congress decided that as of July 1975 an aged, blind, or disabled person needs $\$ 157.70$ a month to meet basic living needs, and thus increased the federal cash benefit accordingly. The benefit for an aged couple is now $\$ 236.60$ a month. An individual or couple who have income slightly above these amounts may still qualify for a partial payment because some income is disregarded or not counted in determining eligibility for benefits.

"At the $\$ 130 / \$ 195$ leve1, 55 percent of the aged individuals, 61 percent of the blind, and 51 percent of the disabled individuals were awarded monthly Federal SSI payments that were higher than their earlier State assistance payments. The corresponding proportions for couples were smaller: about 40 percent among the aged and blind, and 46 percent among the disabled". (Ibid. 23)

Prior to SSI, welfare recipients in 26 states were receiving less than the newly established SSI minimum. In 10 states, 80 percent or more of the aged individuals received higher Federal SSI payments than their former State assistance payments. For couples, fewer states had proportions with increased payments as a result of conversion that were at the higher ranges than was the case for aged individuals.

of particular interest are those persons found eligible for Federal SSI payments whose previous State assistance payments were higher than the maximum Federal payment standards under the new program. For several states the proportion with assistance payments above the Federal SSI maximum payment standard were substantially greater than the national percentage.

In Oregon, while 20 - 30 percent of aged individuals (and $30-40$ 
percent of aged couples) receiving State payments before January 1973 realized an increase in payments under the Federal SSI program, 23.2 percent of aged individuals eligible for Federal SSI were receiving more than $\$ 140$ in December 1973 from the State assistance program, and 52 percent of disabled individuals received $\$ 140$ or more.

\section{State Supplementation}

From the beginning it could be seen that there would be additiona) financial needs for some clients, over and above the Federal SSI standard, particularly in those states where previous welfare payment levels were higher than the newly established SSI payments. The necessity for maintaining these previous payment levels is the job of each state in a supplementation program.

"To assure that individuals coming from state assistance rolls to the Federal program would not undergo a reduction in their former income, Public Law 93-66 (enacted July 1973) established provisions for mandatory state supplementation. These amendments required states to maintain the income of persons receiving $O A A, A B$, and APTD at the December 1973 level under the terms and conditions of the state plan in effect in June 1973". (Ibid. 21)

Mandatory supplementation (or "grandfathering") can be administered by the state or local Welfare department, or the state can contract to have Social Security administer the supplement. The states can also provide optional supplementary payments above the Federal and previous state standards to the extent they choose. Federal law does not require states to provide this assistance. "There are no federal rules for optional supplementation unless the state contracts for 
federal administration of its supplementation program." (Center on Social Welfare Policy and Law, 1975:160)

"There are 32 states in which the Federal Government administers at least part of the state supplementation. In 17 of these states, the Federal Government administers both a mandatory and an optional supplement. In 11 states, the Federal Government administers only a mandatory supplement and there is no optional supplement paid. In 4 states, the Federal Government administers the mandatory supplement and the state administers the optional supplement.

"There are 18 states in which the State administers its own supplement. Of these 18, 16 include administration of both a mandatory and an optional supplement, and 2 include administration of only a mandatory supplement." (Bureau of Supplemental Security Income, 1974:13) Texas, due to conflicts with the State constitution, does not have a mandatory or optional supplement program.

"During the period January - June 1974, al1 of the states that provided only mandatory supplementation showed declines in the number of persons receiving supplementary payments." (Rigby, 1974:23) The gradual closure of State supplementation cases is due to rises in the basic SSI payment levels. Increases in OASDI benefits also reduces the number of persons eligible for the mandatory supplementation.

On the other hand, those states with high payments and broad coverage under their optional supplementation programs have shown considerable increases in their caseloads in the period January - June 1974. All states have tended to recognize food, shelter, clothing, fuel, and utilities as basic "needs." Some states have added such items as 
transportation, telephone, household supplies, and medicine chest supplies, as "special needs." Some states have chosen a supplement to new recipients, that is, people who first became entitled to assistance to the aged, blind and disabled after December 1973 and otherwise would not be necessarily eligible for Federal SSI. The dollar amounts of optional supplementation the states elected to pay demonstrate their recognition of the need for increased income among those newly applying under the SSI program.

"Whether or not an individual receives a mandatory supplement, and the amount of the supplement depends on a comparison of his/her current monthly income including SSI with his/her income in December 1973 including state assistance. The individual receives either the difference between current income and his/her December income, or if there is an optional supplementation program and those benefits would be higher, the optional supplementation amount." (Center on Social Welfare Policy and Law, 1975:159) In some states the supplement has to be added to pre-July 1974 SSI benefit levels instead of the $\$ 146$ or other post-July levels.

Oregon

In Oregon, for example, where the State has chosen to administer both the mandatory and optional supplementation programs, the standard payment amount of $\$ 157.70$ for an aged or disabled individual is added to $\$ 20$ of unearned income (which is disregarded), and then the State supplement is $\$ 5$, bringing the total possible income to $\$ 182.70$ (plus certification for food stamps and medical care). Previously, Oregon Iaw required that, when Federal SSI recipients received a cost-of- 1 iv- 
ing increase, state supplemental payments (OSIP) were reduced by an equal amount. Thus, payment levels did not go up for recipients, and theoretically the state was getting out of the supplementation business as the payments leveis rose. Senate Bi11 761 passed by the 1975 Oregon Legislative session provides that one-half of those cost-of-living increases be passed along to recipients of the state supplement.

All SSI recipients are eligible for Medicaid, and the state requires recipients to make application at the State Public Welfare Division offices. "New SSI recipients eligible for optional supplementation can apply for both Medicaid and supplementation in one document." (The National Senior Citizens Law Center, 1974:151) The Social Security Administration has agreed to determine Medicaid eligibility as well as determination of medical disability. The State will continue to determine eligibility for AFDC, GA, Food Stamps and Medicaid for nursing home cases where the individual has income over $\$ 45$ per month. The State also provides social services for SSI recipients and offers vocational rehabilitation services.

"Effective January 1, 1974, there were approximately 16,000 aged, blind, and disabled converted from State Welfare rolls to SSI. As of July 1974 there are more than 22,000 Oregon residents receiving SSI payments." (Bureau of Supplemental Security Income, 1974:13) This increase in caseload shows Oregon has been responsive to the needs of potential recipients in their optional supplementation program. Although payment levels may not be as high as some would wish, Oregon's standards are among the highest in the nation. 
Advantages to Federal Administration

As was mentioned above, in Oregon in order for an SSI recipient to apply for the State supplement he must go to the Welfare Office. If an original intent of the SSI program was to get away from the Welfare stigmatization seen in categorical assistance programs, Oregon's link to the Welfare Division of their Supplemental Security Income program has only accomplished further stigmatization of recipients.

Had Oregon chosen to have their program federally administered, the applicants would only have to go to one office for determination of both the Federal payment and the State payment for the supplement. Eligibility determination for Medicaid and medical disability could be done at the same time, saving duplication of efforts and records. The Social Security Administration already has access to systems for verification of information for eligibility, and their centralized computer capability would increase responses to inquiries about payments and eligibility both within the state and between other states.

The cost of administration would be totally assumed by the Social Security Administration for administration of the supplement and 50 percent of the costs for determining Medicaid eligibility. During the 1975 Oregon Legislative Session this question of federal administration was introduced. However, the State Welfare Division was in opposition to the measure as they said their caseloads would remain the same while staff would be reduced and that it would be unwise to adopt federal administration under the circumstances. The measure was defeated.

Oregon should yet look into separating the Public Welfare Division from the Bureau of Supplemental Security as the present system tends to 
deter potential recipients from applying for benefits due to the severe stigmatization experienced when associated with the Welfare Division.

Thus, SSI was created to take over previous welfare programs. In doing so, massive changes were called for in federal and local bureaucracies designated to handle the program. The Social Security Administration was asked to reach a new population of people with a new income strategy, and thus has had to undergo many internal changes to accommodate such a monumental task.

State systems have also had to readjust their assistance programs to comply with uniform Federal guidelines. In Oregon, where previous Welfare payments were relatively high, SSI must now be supplemented to maintain income levels. This locally administered supplementation has questionable value in reaching those persons previously unwilling to go to a Welfare office to apply for financial assistance.

I will now turn to look at the literature regarding organizational change to set the stage for analyzing the intraorganizational changes the Social Security Administration was forced to make as a result of the SSI program. 


\section{CHAPTER IV}

\section{THE ORGANIZATIONAL CHANGE PROCESS}

Much attention has been given recently in the field of organizational literature to the phenomenon of change in the structures and functions of an organization.

Traditionally, organizational change has been seen as movement from one state of organizational affairs to another. (Jones, 1969) This static definition is similar to Levine's three-stage concept of change: (1) unfreezing of current behavior, (2) the initiating of new behavior, and (3) the freezing of that new behavior. Hage and Aiken (1970) examined the sequence of events (or change stages) occurring in any alteration of an organization. These stages (evaluation, initiation, implementation, and routinization) describe what we might expect to occur as the organization readjusts its goals and proceeds to implement a new plan. Organizational change in reality is not a static event, but dynamic; different levels of a single organization are likely to be at different stages at any given time, but the static definition provides a useful framework for measuring change.

Leavitt (1965) proposes a continual process of change involving adjustments in four major areas: task, structure, technology (including programs as well as machines), and people. Change in any one of these variables usually results in compensatory changes in the others.

The importance of this background is in realizing that organizational change can be viewed in any number of ways. It can be examined 
by looking at different levels of change in the structure or functioning of any organization, or by analyzing various phenomenon that may occur within or outside of the organization as a result of that change. One way to look at organizational change is to look at the organization and its task environment (or the environment in which the organization performs its functions). Form and Miller propose that "an organization may be regarded as an agent of exchange with its environment. The exchange may be of minimal character. However, governmental, economic, educational and religious organizations tend to make major impacts upon the social system of which they are a part." (Stogdi11, 1967:44) Some authors hypothesize that change in the focal organization ${ }^{*}$ may cause changes in the interorganizational relations of that organization (meaning, relationships the organization may have with other organizations).

As Baker (1969) points out, "open-systems theory was developed in order to relate the whole ... organization to elements in its environment." (Baker, 1969:404) White (1974) has shown that the formation of linkages with other community agencies may be at least partly explained by the structures and practices inside the focal organization itself. "The importance of the environment and of interorganizational relationships in the conceptualization of the functioning of an enterprise has become the subject of increasing attention by organization researchers and theorists (e.g., Etzioni, 1960; Levine and White, 1961; Emery and Trist, 1965)." (Ibid.)

\footnotetext{
* (Here the focal organization is defined as the particular organization that is the point of reference; Stogdi11, 1963).
} 
Thus, there is a rising concern among current researchers to link what goes on in the focal organization to the interorganizational field. In fact, Hage and Aiken's model of change results in a final end state of change referred to as "routinization." One way to measure this socalled routinization is to look at the degree to which the new program has become integrated within the focal organization itself and how welldefined the program and organization's domain ${ }^{*}$ is.

In order to study the nature of the change process involved in the implementation of SSI by the Social Security Administration and how this in turn relates to interorganizational issues, the Hage and Aiken four-stage model of change was chosen as a framework.

This model is based on looking at an alteration in the goals of an organization and how such an alteration sets off a cycle of change in the organization itself necessary to accommodate the new goals. It also provides a time line structure of tasks to be accomplished in the change process that helps to identify how an organization is adjusting to a change in goals. As Baker (1969) suggests, in addition to developing indicators of certain outcome characteristics at the end of a change in goals, "it is particularly important to study the processes by which the organization searches for, adapts to, and resolves its changing goals." (Baker, 1969:403)

Each stage presents organizational decision makers with critical organizational problems to be solved. Although there may be no clearly

*Levine, White and Paul (1969:17) suggest an organization's domain "consists of the specific goals it wishes to pursue and the functions it seeks to undertake in order to achieve these goals." Warren's definition of organizational domain includes the organization's "locus" in the interorganizational field. 
defined end to one stage and a marking of the beginning of the next stage, they are useful analytical categories to assist in understanding the process of change. The Hage and Aiken model provides a framework by which we can look at the changes occurring in the Social Security Administration (and any concommitant changes occurring in the environment) as a result of the Supplemental Security Income Program.

I will now present the model of what Hage and Aiken predict should occur in each change stage.

Evaluation Stage

"The beginning of the process of organizational change occurs when organization decision makers determine that either the organization is not accomplishing its present goals as effectively or efficiently as possible or when decision makers alter or amend the goals of the organization." (Hage and Aiken, 1970:94) This is a period of study and assessment of needs 。

The decision to make a change may result from a study of various aspects of organizational performance: the volume of production, the efficiency of production, or the morale of organizational members. Many organizations make periodic evaluations to analyze whether the organization is meeting its objectives.

During the evaluation stage, decision makers "assess the state of health of an organization, consider alternative ways of correcting organizational problems, and then decide on one alternative that hopefully will accomplish the desired ends." (Ibid. 95) In the choice of a solution the organization faces a dilemma. On the one hand, the organization can make a modest change that does not deviate noticeably from the 
previous product or service of the organization. On the other hand, the organization can choose a solution that represents a radical departure from previous organizational activities. The disadvantage of the former is that the change may not solve the problem, while the disadvantage of the latter is that the risk may be too great and threaten the existence of the organization.

The greater the scope of the new program, the more acute the problems become. Then, too, the solution chosen may be perceived by the elite decision makers as meeting the needs of the customers or clientele, when it may not in fact do so.

In any event, the decision about the future course of the organization predisposes the organization to the second stage, the actual initiation of the new program.

\section{Initiation Stage}

When decision makers have decided to add a new activity -- whether it be a new product for a business firm or a new social service in a health or welfare organization -- the decision reflects "long, arduous hours of deliberation" about the appropriateness of the particular solution for the organizational problem.

The decision is likely to start a chain reaction, triggering other organizational phenomena. Organizations are highly interdependent and change in one part is likely to have effects throughout the organization, and other parts of the organization will have problems of adjustment.

One of the first problems the organization must face is to find prospective job applicants with the skills and training needed to fill 
the slots created by the addition of a new program. Job applicants may be recruited either from outside the organization or from with in the existing staff. The more radical the new program (as viewed from the organization's previous history), the more organizational decision makers will probably have to rely on external recruitment for personnel. However, this creates problems in itself. "Bringing in strangers to implement a new program increases the likelihood of resistance to innovation by staff members already in the organization." (Ibid. 97)

It has been found that if decision makers recruit from within the organization "they are likely to select individuals who may be unaware of the full potentialities of the new program." (Ibid.) Further, the "longer job applicants remain in an organization, the more they tend to develop a particular, and sometimes limited, point of view that can seriously mitigate the extent of the proposed change ..." (Ibid.)

Armitage (1974) discusses internal promotion in a social welfare agency and explains a problem arising from this system:

Contact with clients is limited to the lower-ranking personnel of the organization who are least able to produce change in policy. Furthermore, organizational policy in effect, if not by intent, tends to discourage sensitivity to the client. Promotion, for example, means that the ... worker takes a step away from the client and a step deeper into the organization. The best candidate for such promotion will be the worker who is interested in the organization rather than in the client. Hence the promotion structure discourages the worker from articulating client-centered interests. (Armitage, 1974:307)

Another aspect of the initiation stage is the search for financial support for the new program. If the funding is sought from outside of the organization it may only be temporary and may result in some loss 
of control, or autonomy if the financing means becoming involved in joint programs. Hage and Aiken discuss the loss of autonomy that sometimes occurs with federally sponsored programs that exercise control over the nature and content of programs.

On the other hand, if financing is done from within the organization, part of another program may be curtailed because of scarcity of funds.

Implementation Stage

It is in this stage that disequilibrium of the organization is greatest. The previous two stages normally involve only the elite of the organization, those making decisions regarding organizational goals, staffing, and funding. However, during the implementation stage, the program becomes a reality. No matter how much the elite may plan, a plan is unlikely to consider all the potential sources of discontinuity between the new program and the existing organizational structure.

The addition of a new program may create conflict among staff, especially when new positions are created. The occupants of the new positions will fight for power for the right to make rules, and for a share of the rewards of the organization. The new job occupants may want more authority in order to establish their new activity successful1y. They may demand more space or other resources in order to do their job.

These requests present a dilemma for the organizational elite as acceding to these demands may help the implementation of the new program but may result in alterations in existing structures, which will cause other job occupants to resist the change. 
"Another factor making the implementation stage difficult is that frequently the success of a new program requires the active cooperation of other members of the organization." (Hage and Aiken, 1970:101) If the lower participants in the organization (those concerned with the actual operation of $i t$ ) do not cooperate, the program can be largely a failure due to this passive or even active resistance.

This stage often involves a struggle over power. If the organization elects to share decision-making power with its task environment and use human relations techniques, the active cooperation of the community is much more likely. However, if the organization shares its power, it runs the risk that the program plan may be altered considerably as a result. The stage of implementation is thus a stage in which the organization must attempt to maximize change and minimize resistance to the change.

Another problem associated with the implementation of a new program is that the program may be a good idea on paper, but the planning may not have accounted for every contingency in the program and as a consequence, the program must be altered as it is being established. This situation creates a continual strain on the interpersonal and "interpositional" relationships connected with the new program. This strain may become manifested in some form of social conflict, seen between organization members and/or interagency relationships that are based on the new program activity.

\section{Routinization Stage}

At some point the organizational elite must decide whether the program is meeting the need for which it was designed. The new program must 
be evaluated by some measure of success or failure. Thus, research is done to determine whether to retain the program in tact, retain it with further modifications, or drop it entirely. Hage and Aiken predict that "the more the criteria include measures of efficiency, the more likely the new program might be rejected." (Ibid. 105)

If the elite decide to keep the new program, a period of consolidation is begun. "What was a new activity becomes integrated into the existing structure." (Ibid.) If the innovation is abandoned, the organization may revert to the pattern existing prior to the initiation stage. If the program is continued, rules and regulations must be developed, which may involve writing rules manuals as well as detail job descriptions for the new positions created. The development of job training programs is begun to help new job occupants to become familiar with their responsibilities and become involved in the daily operations of the organization. "The decision to standardize a program marks the beginning of the routinization stage." (Ibid.)

Once the decision to keep the program is made there ensues a period of trial and error, as the new program cannot be completely planned in advance. There will be alterations or modifications as the personnel associated with the new program attempt to make it work. Hage and Aiken hypothesize that the longer this period of trial and error is allowed to continue, the greater the chances for the new program to achieve its objectives. However, this period engenders conflicts costly to the organization, thus encouraging the elite to routinize the program into the existing structure as soon as possible.

Closely related to establishing rules and procedures is the prob- 
lem of defining a proper role for the new program within the existing structure. The program must be articulated with other programs and the policies and procedures made congruent with other parts of the organization.

Perhaps the best sign of the routinization of a new program is when the people originally involved in implementing the program are replaced. If the program remains in tact, we can say the program is stabilized。

Thus, each stage has specific characteristics or developmental tasks to be achieved that mark an organization's progress or "success" in undergoing a change in goals

I will now proceed to look at how the Social Security Administration passed through each of these stages with the adoption of the Supplemental Security Income Program。 


\section{CHAPTER V}

\section{EVALUATION STAGE -- \\ THE SOCIAL SECURITY ADMINISTRATION}

As you will recall, in this initial stage, only the organizational elite are involved and the decision to execute a program change is made. In the case of SSI, the program was developed through legislative action and the Social Security Administration was mandated to alter its goals and adopt the new program.

SSI represented an alteration in the goals of the Social Security Administration for several reasons. First, the conceptual format of SSI is based on providing an income floor to those who meet complex need, income and asset criteria. OASDI (01d Age, Survivors and Disability Insurance) payments, on the other hand, have always been based on the concept of "earned" income. This change, according to Hage and Aiken, represents a "radical departure" in organizational activities. Second, the population served by the Social Security Administration changed to include the destitute, rather than serving retired "workers。" Likewise, screening for eligibility and the application of means tests for SSI recipients are carried out within the Social Security Administration itself. This likens the SSI application process to that of previous welfare programs.

The Social Security Administration had prided itself on its efficient money-management system. It was this attribute that decisionmakers noted when considering who would administer the new supplemental 
income program. It was hoped that the prestige of Social Security could be brought to the public assistance area, in that people who were reluctant to apply for welfare would be more willing to apply for SSI. Thus, segments of the "deserving poor" could be reached.

With the development of SSI, the Social Security Administration was forced to incorporate a welfare-type program into their insurance system. This necessitated drastic intraorganizational changes be made to incorporate the program. It was estimated by the Social Security Administration that by June 1975 some 5.1 million persons would be receiving SSI benefits, with nearly 40 percent of them being new recipients of assistance。 (Cardwe11, 1974) It was further estimated that many of these new recipients would have had no previous experience with public assistance programs.

Consequently, it was by design that SSI would involve Social Security Administration staff in the provision of valuable "information and referral" services to relatively naive individuals. In other words, the new legislation put the Social Security Administration directly within the social service system of the local community. For the first time, the Social Security Administration was mandated to not only become familiar with the service community, but to coordinate efforts with the service community in the implementation of SSI, thus forcing, presumably, new sets of relationships within the existing social service networks。

Nevertheless, in the evaluation stage only the elite of the organization, primarily national leaders, were really involved in the change process. While it might have been beneficial at this point for 
community service personnel to relate to possible complications they might have foreseen in the Social Security Administration handling SSI, interorganizational communication did not exist per se. The Social Security Administration did not seek help from service personnel in planning for new goals. Had they consulted with the service community during this stage, that, in itself, would have marked a change in agency practices.

Hence, from the beginning, the Social Security Administration handled with SSI program autonomously. As we will see, this became the predominant pattern throughout the implementation effort and perhaps yet exists today。

We now move into the second phase of the change process. 
It was in this stage that the pros and cons of the Social Security Administration handling SSI were debated legislatively. The Department of Health, Education and Welfare chose the Social Security Administration to be responsible for administering SSI. Of all the federal and state level assistance and welfare programs, the public image of the Social Security Administration as a government insurance agency in the United States has remained strong and untarnished. (Hollister, 1974; Goodwin and Tu, 1974) Other relief strategies have fought the stigmatization attached to their programs, thus the consistent "clean" public image of the Social Security Administration has been a hallmark of the agency, and something they did not wish to surrender.

Perrow (1961) discusses the importance of public image of the organization to the organization's internal workings, and thus when the Social Security Administration was asked to administer SSI, it was for the benefit of the new recipients who might choose to do business with the Social Security Administration, when they had previously disdained Welfare. Senator Long is quoted in the Congressional Record as stating the aim of SSI is to "assure program integrity through administrative control where this has shown to be needed." (Long, 1972:32471) And further, that SSI would "restore the INTEGRITY (emphasis added) of the Welfare programs。" (Ibid. 32475) 
The Social Security Administration was seen as an agency with a "long and distinguished record of efficiency" that has operated OASDI in such a way as to create "wide applicability of the program among recipients and potential recipients。" (Williams, 1973:13) The Social Security Administration had previously used an earnings test in the OASDI program and verified claims by data from the Internal Revenue Service. This checking was done with "due care for the rights and sensitivities of the aged recipients, seemingly with the clear presumption that beneficiaries are honest persons (innocent until shown guilty of cheating) which hardly has been the basic presumption of public assistance." (Ibid。)

However, in planning for the administration of SSI, the Senate Finance Committee emphasized that while the Social Security Administration would handle both the new SSI program and the 01d Age, Survivors, and Disability Insurance program, they had no intentions of merging the two programs. Each was to maintain its own identity and this uniqueness was stressed by requiring separate applications and reports for each type of benefit and in particular, by issuing separate benefit checks of different colors.

So, intraorganizationally, the Social Security Administration undertook a new program, but had had previous experience with a similar system, at least mechanically. The public image of the focal organization (SSA) at this point, was an outstanding characteristic, and very important to maintain. Therefore, from the beginning, the SSI program was differentiated from insurance programs administered by the Social Security Administration. This differentiation can be seen as the 
Social Security Administration's way of keeping separate "earned" from "relief" income. If this was (and is) the case, it seems pointless to hope the SSI program would benefit from the "clean" image of the Social Security Administration when the Administration itself did not accept SSI as an equal to OASDI.

As Hage and Aiken mention, finding job applicants to fill the new positions created by the program change is a major problem in this stage. The Social Security Administration has a definite policy of hiring and promoting from within the organization and this has seemed to minimize some of the internal conflict developed by changes of the organization. Hage and Aiken (1970) and Armitage (1974) see this as an advantage initially, because internal recruitment tends to cut down on the resistance to innovation by existing staff by promoting effort for achievement of higher status. However, this can be seen as a barrier to further internal changes. Existing staff may have a limited view of the new program and may accept the new position as a promotion away from the clients, when in this case, dealing with SSI recipients involved more intensive contact with clients than before. Potential SSI recipients are often times also in need of other social or medical support programs and therefore need referrals to appropriate agencies. Respondents in the community survey suggested to us that trained social workers be located in the Social Security Administration District Office so that problem cases could be dealt with properly. Multiproblem clients must still seek supportive help beyond cash payments. In Oregon the Public Welfare Division has always handled these clients and has offered supportive services. It was argued that perhaps the 
Social Security Administration should not administer SSI under the circumstances because the previous categorical ass istance programs were more efficient as a total social service approach, providing more than just money.

It appears that in recruiting staff from within the organization, the Social Security Administration encountered problems in the completion of the initiation stage. Besides the lack of training given to employees regarding the massive changes in forms, procedures, and clientele, staff are yet being evaluated according to the old criteria of efficiency and effectiveness that were used with the more traditional, non-welfare-like clients of Social Security.

As Armitage (1974) suggested, measuring performance by efficiency tends to discourage the worker from articulating $\mathrm{client-centered} \mathrm{inter-}$ ests. In order to change the reward system now based on achievement and success, the system would have to be changed to distribute money rewards in such a way as to encourage client-centeredness rather than organization-centeredness.

Social Security staff are overburdened and uninformed and thus were portrayed by community service providers as uninterested in social services. (This may accurately reflect Social Security Administration employee sentiment.) The previous fast, efficient performances by Social Security Administration employees were seen by the community providers interviewed for this study as slow, incorrect, or troublesome. Some agencies resigned themselves to not initiating dealings with the Social Security Administration unless a problem arose with one of their clients. In that case, they acted as an advocate concern- 
ing the applicant's eligibility for benefits. Although the staff performances were not evident until the program actually began (in the Implementation Stage), I have chosen to discuss them here as a problem in the initial recruitment of staff。

Another task of the Initiation Stage is to secure funding for the new program. The Social Security Administration faced no problems concerning recruitment of funding, or expansion of internal funding for SSI that might endanger other Social Security programs. However, other Social Security programs are funded from payroll taxes and represent work-related income, whereas SSI is funded from the general revenue and can be seen as public assistance. This change in source of funding may be disquieting to the Social Security Administration and equivalent to "going outside the organization" for funding. In practice, although the Social Security Administration has distinguished emphatically between OASDI payments and SSI payments right down to the color of checks, both OASDI and SSI are transfers from workers to non-workers. So, in reality, there is no difference, but the public and the Social Security Administration both view the sources as different.

Actual1y, during the initiation stage there was no (interorganizational) contact between the Social Security Administration and the environment. The SSI program had not begun yet, so the only changes we can speculate about were those within the focal organization itself. The Social Security Administration was chosen to manage the SSI program for two major reasons. Its past history was marked by efficiency in performance of a similar task mechanically, and the high prestige associated with Social Security programs was hoped to carry over to 
SSI. However, SSI was and is totally differentiated from OASDI so the latter objective seems dubious.

The Social Security Administration continued to run its program autonomously. SSI was funded without the need for Social Security to recruit funds or alter existing programs. Staff were promoted from within the structure to handle SSI, but in doing so, needed training to accompany the changes in clientele and procedures was neglected. As will be seen in the next stage, the problems of prestige and efficient performances continued to be a major concern as the SSI program was implemented。 


\section{CHAPTER VII}

\section{THE IMPLEMENTATION STAGE -- \\ THE SOCIAL SECURITY ADMINISTRATION}

It is in this stage that the organization actually begins a new program. As Hage and Aiken outlined, major conflicts arise, of ten in struggles over power and in cooperation with the task environment. Hage and Aiken posit that with the creation of new positions, the job occupants will want to exercise their rights to make rules and share in the power of authority in the organization.

In the Portland District Office of the Social Security Administration a special SSI "Crunch Unit" was set up to handle problem SSI cases. Nevertheless, this does not seem to reflect staff concern for the special needs of SSI recipients, but rather, an administrative decision of how best to structure the office and further segregate the staff that handle SSI。 Litwak (1961) suggests the physical segregation strategy may be one way to mix bureaucracy and human relations functions in one organization.

Respondents from this community survey suggested Social Security staff have rejected the lower status role given those who work with "welfare" clients. On the job with clients and within the community, staff have been heard to say, "we don't do social work here."

Thus, in the Social Security Administration we have seen possible administrative as well as line staff rejection of the lower status role associated with SSI workers. Because of this we may see a further 
differentiation of the SSI program someday into physically segregated bureaus, with professionally trained staff to deal with SSI clients. Many of the service agencies interviewed for this study would like to see this professionalization take place.

Another major factor in the implementation stage described by Hage and Aiken is the requirement of the cooperation from organization members in implementing the program and the importance of this to the success or failure of the program. In the case of SSI, an informationa1 campaign was undertaken to promote the program. The campaign was known as the SSI Alert. Since the Alert was of major importance to the SSI implementation effort as a whole, I have included a thorough discussion of the SSI Alert, its development and subsequent effect in Oregon particularly.

\section{Project SSI Alert -- Phase I}

Walter Williams (1973), in a public policy address, suggested the Social Security Administration promote the implementation of SSI in these ways:

1. Written, oral and visual materials describing SSI in socially acceptable terms as a federal income guarantee ...;

2. Staff procedures for SSA local offices that minimize as much as possible differential treatment between SSI and OASDI recipients;

3. Eligibility standards and procedures for determining eligibility that are both nonintrusive and simple;

4. Training techniques intended to orient SSA local staffs concerning technical information about the program and SSI's rationale; 
5. An outreach campaign aimed at insuring that all eligible persons are aware of the SSI benefits to which they are entitled; and

6. An effort to induce states to use SSI for cash supplemental and Medicaid payment, make their rules and procedures for related programs more in line with those of SSI, and keep up the level of their payments so that combined SSI-State benefits do not fall below the earlier State payments. (Williams, 1973:30)

He stressed that the Social Security Administration should present to potential recipients that they deserve or have a right to their SSI payments and thus liken it to OASDI, further distinguishing it from Welfare。

On November 13, 1973, "Project SSI Alert" was announced to Social Security Administration Regional Representatives, District, Branch and Teleservice Managers from the Bureau of District Office Operations. This project was designed to reach and provide assistance to aged, blind and disabled as an important part of the Social Security Administration's information and referral programs. The purposes of the alert were:

1. To enlist the help of the media to explain SSI and who is eligible, and for the Social Security Administration to continue this responsibility.

2. To provide a focal point for recruitment, training, and use of volunteers who were to explain to individuals and/or groups the program and how to determine eligibility.

3. To utilize personnel in other agencies to help identify potential recipients and make written referrals to the District 
Office of the Social Security Administration.

4. To assist individuals in self-screening for potential eligibility for SSI。

5. To provide volunteer-supported procedures to receive, record, and transfer names and addresses of potential recipients to the District Offices of the Social Security Administration.

The organization of the Alert involved governmental agencies and private voluntary associations at national and local levels. The District Managers of Social Security offices were the first to be contacted by the local leader of the SSI Alert project, and they were to work with the leader, the Red Cross, and other participating organizations. Prior to the project's beginning, these District Managers were supposed to not only identify SSI "information and referral" and public information programs in their local areas, but to arrange a pre-implementation and an ongoing public information campaign within the framework of national efforts. District Managers were further responsible for providing technical staff to train volunteers who would explain SSI to potential eligibles. As of April 1974 the Administration on Aging, under Dr. Authur Fleming, agreed to expedite the Alert by providing lists of potential recipients identified by a screening of the master beneficiary record. The closing date for Phase I of the Alert was June 30, 1974. In Oregon, and particularly in Portland, all this "coordination of efforts" did not take place. A Model Cities agency (Project ABLE) screened for potential SSI eligibles and referred these persons for determination. Project ABLE was functioning long before SSI was implemented, thus the Alert was seen by the Social Security Administration 
as duplicative.

The Social Security Administration apparently was not involved in any coordinated program for informational campaigns or eligibility referrals, but carried on their own program separately. Portland apparently was unique in their efforts during the SSI Alert. A review of events has produced a picture of confusion and little coordination between Social Security Offices and local agencies involved in the SSI Alert.

Project SSI Alert -- Phase II

The intent of the Alert Phase II was to create better understanding and better working relationships between the Social Security Administration and community service programs for the aged. This effort was initiated in the summer and fall of 1974 as a follow-up on the leads lists of those potential eligibles. It involved a decentralized mailing operation under District and Branch Managers, including a selfscreening questionnaire to be sent out. Volunteers and temporary employees were to man the operation, and do home visitation where necessary to further explain SSI, in addition to the mailing campaign. The Social Security Administration was asked by the Administration on Aging to concentrate on these home visits and special training needed to be given to those volunteers and employees making the visits.

Since the responsibility for the master beneficiary record listing fell on the Social Security Administration at a time when they were already extremely busy, the mail-out campaign accomplished was of questionable effectiveness. Social Security Administration offices were again reluctant to participate in the Alert and use volunteers from out- 
side organizations. The Downtown Portland Office had no volunteer involvement, yet relied on staff to conduct telephone screening. They tended to prefer the autonomy to run the program themselves, and not be involved in other "coordinated" efforts. The question of confidentiality had not been resolved, which further alienated Social Security.

To return to the community survey used for this study, when asked if the SSI Alert had any effect on their agency's relations with the Social Security Administration, 13 out of 21 respondents said it had no effect. Some said the Alert "didn't work well," or that they thought the Social Security Administration was unaware their agency was even involved in the Alert. Of the 7 saying it did have an effect, responses tended to point to increased dealings with the Social Security Administration, some improved dealings, and help the agency gave to the Social Security Administration (not vice versa).

There was no indication that the Alert helped disseminate information to a great extent, or draw the Social Security Administration directly into the service community. In fact, we received negative comments regarding the Social Security Administration's lack of outreach, lack of cooperation in working with the local sector, and general lack of help given to potential SSI recipients. One respondent was not convinced there even was an SSI Alert.

Two comments of particular interest were that the Alert seemed to draw the community into the Social Security Administration (instead of vice versa as hypothesized); and one respondent who said he did not know how effective the Alert was because the Welfare Division handled all the dealings with the Social Security Administration -- while a 
Public Welfare Division respondent said Welfare was not involved in the Alert!

Thus the SSI program created what Rosengren (1970) refers to as an "increasing demand for interorganizational contact and collaboration" during the Alert. Agencies were dependent on the Social Security Administration's leads list of potential recipients, but were not given full access to it. The Social Security Administration not only withheld information from agencies involved in the Alert, but interfered with the overall process; essentially this interference can be viewed as conflict since collaboration not only did not occur, but was seemingly avoided. The Social Security Administration consistently operated as they had done before, autonomously, while collaboration might have helped reach potential SSI eligibles.

Perhaps this occurred as Litwak (1961) suggests because conflict is likely to develop when organizations oriented towards similar or the same tasks (characterized by impersonality of relations, an emphasis on hierarchical authority and an emphasis on general rules and specialization, etc., which could characterize the Social Security Administration) interact with organizations oriented towards non-uniform tasks (such as human-relations organizations with contrasting characteristics).

Dutton and Walton (1966) discuss mutual task dependence, which refers to the extent to which two or more organizations depend on each other for assistance, information, compliance or other coordinative acts in the performance of respective tasks. They suggest such task dependence provides an incentive for collaboration as well as an occasion for conflict. So while the SSI Alert might have been an occasion 
for collaboration, the literature and the responses from the community survey show that the Alert was an occasion for conflict and confusion, here in Portland. (Conflict is thus operationally defined as the opposite of collaboration, where collaboration is seen as a codified goal of the Social Security Administration.)

Thus while a major task of this stage is to achieve cooperation among organization members in implementing a new program, we have seen that the Social Security Administration did not cooperate internally with program goals and attempt to collaborate in order to properiy implement SSI. This has been a major drawback since the beginning and seriously hampered the adjustment of local Social Security Administration staff and community providers to the new program, not to mention potential SSI recipients.

By not fully cooperating with the national implementation project Social Security staff showed resistance to the change in program functioning. Minimization of this resistance should have been the goal in this stage. Since it was not, we may say the Social Security Administration experienced, and is yet experiencing, difficulties because of the implementation of SSI.

We have seen a "continual strain" placed on staff and on community providers because of the many changes in procedures regarding SSI since its implementation. This first resulted in service agencies calling the Social Security Administration in order to advocate for clients having difficulty with eligibility or application for SSI. Sixteen out of 25 respondents in the community survey noticed a change in their contacts with the Social Security Administration since January 
1974. Some mentioned their contacts increased greatly but they were disappointed with the "cut and dried" paperwork of the Social Security Administration. Many reported that their contacts with the Social Security Administration have subsequently dropped off as the program has "worked out the bugs."

In one sense, we have seen a positive progression in the change process of the program being altered and solutions to initial program problems being worked out. On the other hand, communicative ties between the Social Security Administration and community providers are linked only with procedural problems, but not collaborative efforts.

In this stage of change, there has continued to be a differentiation of the SSI program by the Social Security Administration, such that staff reject SSI as lower in status than other Social Security programs. Although, as Williams (1973) suggested, a public information campaign was designed to present SSI to potential recipients as a "right."

Throughout the Alert the Social Security Administration maintained a separate focus -- an "inner-directed" focus -- rather than one centered on collaboration with the community system. As we turn now to the final stage in the change process we will again see a discrepancy between written objectives and actual practices with regard to interaction with the community. 
It is this last stage that the Social Security Administration is now experiencing. This research effort is one indication that the organizational elite are examining whether the program is meeting the need for which it was designed. As Hage and Aiken (1970) suggest, the more the success criteria include measures of efficiency, the more likely the new program will be seen as a failure and will be rejected. This model might pose a problem for the Social Security Administration, hypothesizing that the success of the SSI program will be measured by the efficiency of the system. The Social Security Administration has long been known for efficiency, rather than for a more humanistic quality of service.

Rosengren (1970) suggested a major concern for modern service organizations is the dual demand for efficiency and humanism. With the implementation of SSI, staff were burdened with new policies and constantly changing procedures, while at the same time asked to develop interviewing skills with an increased sensitivity to the needs of the public they serve. These interviewing duties are an essential part of the information and referral services as outlined by the Social Security Administration.

In investigating specifically what these duties entailed, much evidence was found. The detailed handbooks of procedures and policies 
regarding programs are one way the Social Security Administration has attempted to codify the SSI program, according to Hage and Aiken.

The SSA Service Manual (U.S., D.H.E.W., 1974a: Section 9300) describes the role of information and referral services within the Social Security Administration: "An essential part of Social Security Administration's service to the public is the providing of information about the programs and services of other public and voluntary services." The Manual acknowledges that many people cal1, write, or come to the District Offices with problems outside of the scope of the Social Security program, and "accepts the responsibility to provide information on other programs." (Ibid.) It goes on to suggest the public image of the Administration is fixed not only by the way they administer the Social Security programs, but by their "concern for the individual," by the manner in which questions are answered, and by their "demonstrated willingness to help." Such a referral service supposedly not only helps the individual but helps to achieve the "stated objectives of the social security programs."

The Manual says "interviewers must exercise the degree of perception necessary to identify whether an individual is seeking or needs information and referral services ... SSA employees must develop in their interviewing skills an increased sensitivity to the needs of the public they serve," (Ibid. Section 9302) thereby helping to improve (via I and $R$ services) the quality of the life of the individual.

Beyond providing the requisite information, if the interviewer senses the individual is "confused, emotionally upset, or otherwise unable to act effectively, special help may be given." (Ibid. Section 
9312) This help may consist of setting up an appointment for the individual with the referral agency, and writing the address and time down for the individual. In extreme cases, mediation without the individual's consent may be done. In either case, a standard referral form is to be used for any referral made (other than telephone referrals) "to expedite the referral process" and ease the caller's introduction to the serving agency." (Ibid. Section 9303.2)

The types of referrals to be made include: to the Internal Revenue Service or a tax agency for tax assistance; to health or welfare agencies for medical assistance; to social welfare agencies to help the individual maintain his independence and live on in his own home; to voluntary organizations for social contacts; to governmental agencies to help with loans or improve housing or education; to legal aid bureaus for legal advice or assistance; or to human relations commissions when a person has complained of discrimination based on age, sex, race, creed, etc. (particularly with regard to housing, employment or governmental services). Programs for the aged to which District Offices are to make referrals include: homemaker services, protective services, meals-on-wheels, visiting nurse services, adult education programs, and senior centers.

The SSI Handbook (U.S., D.H.E.W., 1974b) elaborates on the public information program that is a part of the referral service, describing the use of publications, posters, and films available for the public. The Districit Office staff are to make presentations before "civic, labor, medical, farm, management, school, and other groups and organizations interested in the social security program." (Ibid.10-11) In 
addition to making available various media regarding Social Security programs for others to use, the Social Security Administration is supposed to promote this information through such media as newspapers, magazines, radio and television.

These regulations specify what the Social Security Administration should be doing on a daily basis. They were extracted from an in-house document that serves as the basic law of the program and presumably reflects a formal ideal role for the Social Security Administration.

The community survey inquired about the nature and frequency of contacts agencies had with the Social Security Administration. Nineteen out of 27 respondents said they do have contact with the Social Security Administration, but 16 of the 19 said their agency initiates the contact with the Social Security office and that the contact is not reciprocated. The nature of contacts generally revolves around troubleshooting for clients or obtaining information for research. Generally service persons have more contact (ranging from 1-12 contacts per month) with Social Security Administration staff than do administrators. This is a predictable phenomenon according to Stogdil1 (1967:44), who states: "contacts and negotiations between organizations tend to be carried out by members with similar functions and equivalent status rankings." We received negative comments about the Social Security Administration's refusal to make referrals and that Social Security makes few or no referrals, except to the Public Welfare Division. These referrals are automatic in Oregon, as every SSI applicant is given a form to present to the Welfare Division to apply for the Oregon Supplementary Income Program (OSIP). A common practice at the Social Security Adminis- 
tration is to refer clients to welfare for interim payments, as clearance on SSI disability claims particularly can take several months. If SSI intends to offer payments to the deserving poor without the traditional stigma associated with Welfare, perhaps this common referral should be reexamined.

-- TABLE I GOES ABOUT HERE --

Table I shows that of the 400 individuals interviewed for the SSI Impact Study, only $10(2.5 \%)$ were referred to another agency by the Social Security Administration. Four of the 10 referrals were to the Welfare Division. This is a very significant finding, as 82 of these 400 elderly were, at the time of the interview, receiving SSI benefits, and another 275 were receiving OASDI benefits. Two hundred eighty-one of the sample had actually contacted the Social Security Administration within the last several years, with the mean being within the last oneto-two years (within the time since SSI was implemented and hence the information and referral goals).

Thirty-two percent of all contacts made to the Social Security Administration by this sample were made by phone. However, 38.6 percent of these phone contacts reportedly produced not enough or no help at a.11 for the elderly caller. Further, often times workers in the Social Security office will make an informal determination for SSI eligibility by phone. Of those in this sample who were told they were ineligible for SSI benefits $(n=26), 14(53.8 \%)$ were informed by phone. These elderly supposedly did not pursue their eligibility beyond that initial phone determination. By looking at the overall low income levels of the 
TABLE I

DID SSA REFER YOU?*

Absolute
Yes
No


sample as a whole, it is possible some of these persons would have been eligible for benefits had a full review of their situation been made.

-- TABLE II GOES ABOUT HERE --

Another area for concern about Social Security Administration practices is brought out by the Center on Social Welfare Policy and Law (1975) where it states Social Security staff are not supposed to volunteer information about the emergency advance payments available to recipients, but should wait to see if the individual asks for help or otherwise mentions facts which indicate that an emergency exists. Also, if an SSI claimant wants vocational rehabilitation he should ask for it himself and he is entitled to a hearing is refused benefits, although this information is not always passed along to clients as it should be.

There obviously appears to be a big discrepancy between the information and referral services outlined by the Social Security Administration and actual practice. The Social Security Administration is represented on the Portland Federal Executive Board (as well as other planning bodies), which has discussed information and referral services in the Portland area. However, unless the Social Security Administration concretizes this plan on their own staff level, the role of information and referral services in the Social Security Administration's overall functioning appears nebulous at best.

The production of the detailed job descriptions and policies regarding SSI is one way the focal organization has tried to formalize the new program and "integrate" it within the federal bureaucracy of human resources. By doing this, the Social Security Administration has attempt- 
TABLE II

HOW CONTACTED SSA

\begin{tabular}{|c|c|c|c|c|}
\hline $\begin{array}{l}\text { Count } \\
\text { Row Percent } \\
\text { Column Percent } \\
\text { Total Percent }\end{array}$ & $\begin{array}{l}\text { Visited } \\
\text { In } \\
\text { Person }\end{array}$ & Telephoned & $\begin{array}{l}\text { Wrote } \\
\text { Them }\end{array}$ & $\begin{array}{c}\text { Row } \\
\text { Total }\end{array}$ \\
\hline \multicolumn{5}{|l|}{ WHAT HAPPENED: } \\
\hline $\begin{array}{l}\text { Satisfactorily } \\
\text { Helped }\end{array}$ & $\begin{array}{r}111 \\
66.1 \\
66.1 \\
42.4\end{array}$ & $\begin{array}{r}50 \\
19.8 \\
60.2 \\
19.1\end{array}$ & $\begin{array}{r}7 \\
4.2 \\
63.6 \\
2.7\end{array}$ & $\begin{array}{r}168 \\
64.1\end{array}$ \\
\hline $\begin{array}{l}\text { Got Help but } \\
\text { Not Enough }\end{array}$ & $\begin{array}{r}3 \\
60.0 \\
1.8 \\
1.1\end{array}$ & $\begin{array}{r}1 \\
20.0 \\
1.2 \\
.4\end{array}$ & $\begin{array}{r}1 \\
20.0 \\
9.1 \\
.4\end{array}$ & $\begin{array}{r}5 \\
1.9\end{array}$ \\
\hline $\begin{array}{l}\text { Got Help with } \\
\text { Difficulty }\end{array}$ & $\begin{array}{r}26 \\
74.3 \\
15.5 \\
9.9\end{array}$ & $\begin{array}{r}8 \\
22.9 \\
9.6 \\
3.1\end{array}$ & $\begin{array}{r}1 \\
2.9 \\
9.1 \\
.4\end{array}$ & $\begin{array}{r}35 \\
13.4\end{array}$ \\
\hline $\begin{array}{l}\text { Did Not } \\
\text { Get Help }\end{array}$ & $\begin{array}{r}14 \\
60.9 \\
8.3 \\
5.3\end{array}$ & $\begin{array}{r}9 \\
39.1 \\
10.8 \\
3.4\end{array}$ & $\begin{array}{l}0 \\
0 \\
0 \\
0\end{array}$ & $\begin{array}{r}23 \\
8.8\end{array}$ \\
\hline $\begin{array}{l}\text { Told Not } \\
\text { Eligible }\end{array}$ & $\begin{array}{r}11 \\
42.3 \\
6.5 \\
4.2\end{array}$ & $\begin{array}{r}14 \\
53.8 \\
16.9 \\
5.3\end{array}$ & $\begin{array}{r}1 \\
3.8 \\
9.1 \\
.4\end{array}$ & $\begin{array}{r}26 \\
9.9\end{array}$ \\
\hline $\begin{array}{l}\text { Pending } \\
\text { Determination }\end{array}$ & $\begin{array}{r}3 \\
60.0 \\
1.8 \\
1.1\end{array}$ & $\begin{array}{r}1 \\
20.0 \\
1.2 \\
.4\end{array}$ & $\begin{array}{r}1 \\
20.0 \\
9.1 \\
.4\end{array}$ & $\begin{array}{r}5 \\
1.9\end{array}$ \\
\hline $\begin{array}{l}\text { Column } \\
\text { Total }\end{array}$ & $\begin{array}{r}168 \\
64.1\end{array}$ & $\begin{array}{r}83 \\
31.7\end{array}$ & $\begin{array}{r}11 \\
4.2\end{array}$ & $\begin{array}{r}262 \\
100.0\end{array}$ \\
\hline
\end{tabular}


ed to stake out its domain, and stabilize the program.

During routinization the organization must define a proper role for the new program within the existing organizational structure. Since the information and referral function necessitates interaction with the community, the Social Security Administration was faced with defining a role for SSI and itself within the community structure as well. This involved obtaining domain concensus; and agreement among participants in organizations regarding the appropriate role and scope of an agency.

Thus the community survey was helpful in understanding how successful the Social Security Administration was in passing through this last stage of change. Community providers were asked what role they saw the Social Security Administration playing in providing help to older adults. Twenty-five respondents said they definitely saw the Social Security Administration as a provider of financial assistance or income maintenance to the elderly. Some also connected the Social Security Administration with health care benefits. There was a lot of discrepancy between responses as to whether the Social Security Administration should or could provide direct services to clients. Some said that although there is a need for direct services, the Social Security Administration is not prepared and is not interested in providing social services. Some respondents said the Social Security Administration acts as an educator about benefits, but these persons would like to see an increase in information and referral practices.

Twenty out of 27 respondents said the Social Security Administration could be doing more. Their suggestions included: providing outreach; social services; money management; a comprehensive plan for the 
elderly; emergency funds; and/or working more closely with social service agencies. Others suggested the Social Security Administration publicize more, increase benefits and expedite procedures.

Several respondents felt the Social Security Administration is overworked and understaffed and that they are doing all they can to serve older adults. Some suggested the Federal Government should not be involved in social services at a11, that they are too large and are unable to deal with problems of the eiderly. One respondent stated local agencies are better equipped to deal with such problems.

Findings suggest the Social Security Administration was not generally perceived of as part of the local service delivery system but somehow "outside" of that system. The Social Security Administration was described as a "remote federal banker." Some respondents felt the 01d Age Assistance program administered by Welfare was a more comprehensive system because services and cash payments came from the same agency. SeveraI respondents saw no difference between OAA and SSI and said SSI recipients are really "other Welfare recipients," or at least stigmatized as such. Some felt SSI is "less demeaning" due to the "good" name of the Social Security Administration.

Here we can see that the community does not agree on what the Social Security Administration is or should be doing. There was no grouping of responses between agencies according to any standard organizational measure, such as staff size, budget, type of services provided, number of clientele served, etc. There were no central tendencies in the sense of small-scale, client-focused agencies answering one way, and large-scale, multi-purpose agencies answering another. This is an impor- 
tant finding as it could reflect the uncertainty of role status of the Social Security Administration, which is a further indication of the difficulty this organization is having in integrating the new program.

Domain concensus becomes a key issue here as Warren (1967) describes the greater the domain concensus between community decision organizations the more cooperative their interaction will be. In the converse, domain discensus leads to "contest" behavior, or what Levine, et al (1963) call "conflict," when an organization is judged as not doing as much as it should.

The final mark of the routinization stage according to Hage and Aiken (1970) is the replacement of decision-makers originally associated with the program. This has not occurred in the Social Security Administration. Commissioner Cardwell of the Social Security Administration and Commissioner of Aging Flenming were, at the time of SSI's creation, and are the "commanders-in-chief."

Thus during the routinization stage of the change process the Social Security Administration has attempted to solidify the SSI program by developing "in-house" standards and employee guidelines. Even so, according to this study's findings, the Social Security Administration has been unable to accomplish these goals or objectives. There was an attempt made in the community service providers' interview to get a picture of what their interactions with the Social Security Administration were like before and after the implementation of SSI. We cannot measure precisely what the Social Security Administration was doing before SSI regarding information and referral on an informal basis. Nevertheless, it is clear the Social Security Administration was not fulfilling its 
outlined duties in this area at the time of this study.

The domain of Social Security was and remains in the financial realm. Whether the written objectives to become a provider of social services via I and R will ever become common practice, one may only hypothesize.

I will now summarize the general findings from this study and offer such a hypothes is about why the Social Security Administration has been unwilling or unable to become integrated within the service community. 
CHAPTER IX

\section{SUMMARY AND CONCLUSIONS}

It was hypothesized that when an organization adopts a new program function, the organization necessarily undergoes a process of change while it attempts to incorporate the new program. This study looked at one organization, the Social Security Administration, and how it adapted to a new program, SSI. Hage and Aiken's four-stage model of the change process allowed us to analyze the incorporation of SSI from the beginning stages, where only the federal decision-makers were involved, through the implementation and subsequent routinization of the program.

It was further hypothesized that in the case of SSI, because of the new goal to provide information and referral services, the Social Security Administration was forced to become involved in the community service system. This marked a significant change in organizational relationships for Social Security staff.

The Social Security Administration was created and developed to provide social insurance to a population based on "earned" income. This tradition had become the hallmark of Social Security. In 1972, when the first SSI legislation was passed, the Social Security Administration began designing and implementing those changes needed to incorporate a massive, income maintenance program for the elderly, blind and disabled. During the first phase (Evaluation) of the program change, only the elite were involved in planning. Even though it was known at that time that administering such a program would involve providing informa- 
tion and referral services to a population naive to the service community, community providers were not consulted about how best to implement SSI.

This autonomous administration of SSI was carried into the second stage of change (Initiation) as well. The Social Security Administration recruited for staff from within the organization, rather than hire social service workers experienced in dealing with the previous 0ld Age Assistance program.

Problems arose from this early stage with regard to differentiation of SSI from OASDI payments. Not only were SSI and OASDI checks from different revenues and different colors when issued, but SSI quickly was linked with procedural problems leaving SSA staff seemingly incapable and uninterested in dealing with SSI recipients. Community providers took the role of advocates for clients in their dealings with the Social Security Administration rather than fellow coordinators.

One of the major reasons Social Security was chosen to administer SSI was to better the status of income payments to reach the deserving poor who otherwise resented asking for welfare. According to this study, this has only partially been accomplished. Particularly in Oregon where OSIP payments accompany SSI payments in many cases, recipients still must go to the Welfare Division to apply for benefits.

During the third stage (Implementation) we continued to see the Social Security Administration avoid collaboration with community service providers. The SSI Alert specifically called for internal and external coordination of efforts to implement SSI through a massive public information campaign. While Portland had a community system already 
set up to reach and inform potential eligibles about SSI, the community system viewed the Social Security Administration's refusal to participate further in the Alert as resistive and interfering.

It was during the last stage of change (Routinization) that the specific interorganizational goals of providing information and referral services were examined by looking at discrepancies between ideal and actual practices of Social Security. If the Social Security Administration were to fulfill their written objectives, they would not only need to read and learn about community programs, but become familiar with referring agencies in order to follow through on referrals.

Social Security Administration contacts with agency personnel could have increased tremendously, but they have not. Data from the sample of elderly show very few referrals being made by Social Security. Telephone contacts with the Social Security Administration often are not beneficial; informal eligibility determinations are being made and feedback procedures (such as hearings and appeals) are not being publicized.

The Social Security Administration has always been, and apparently remains, locally defined as a financial institution, and nothing more. The uncertainty of a possible larger role status, though, could leave room for the Administration to turn now and provide social services. The community providers definitely would like the Social Security Administration to do more to help the elderly population.

Why then, when the codified guidelines are already established and the community is willing to let the Social Security Administration into their territory, has the Social Security Administration not done just that? Perhaps there was no incentive to collaborate as was hypothesized. 
Even though "collaboration" is an established program goal, in taking a closer look at the administrative structure of the Social Security Administration we can see that the financial backing of the institution differs from most organizations the literature speaks about.

Levine, et al (1963) hypothesized that organizations are "pushed" into interdependencies with other organizations because of their need for resources. Hage and Aiken see the establishment of joint, cooperative projects with other organizations as a solution to the problem of lack of resources. Hawley (1951) likewise talks about entering into interdependent relationships to secure resources for a program.

The Social Security Administration is not dependent on any other agency for funds and does not need to establish this kind of link with other agencies. Their autonomous funding base renders them virtually independent from any other agency.

Usually in a social system, the focal organization depends on "input" from organizations for various types of resources. (Evan, 1963) These inputs insure the system will be able to exist over time. (Gummer, 1975) In return for these "inputs" the organization produces an "output," or a product. Organizational behavior tends to vary according to how much concentration of activities in the organization is placed on purposeful, goal-seeking behavior (output of the product) or on their system-maintenance activities (input of resources).

"These characteristics of an organization as a social system have a direct bearing upon the capacity or willingness of an organization to engage in interorganizational activities. Namely ... that an organization's willingness to relate to another organization will be a direct 
function of the extent to which that other organization can affect either its inputs or outputs." (Gummer, 1975:35)

In Gummer's study of a public welfare agency he hypothesized that since the resources of the agency were controlled by a "parent" organization, the agency was a "vertically oriented" organization, meaning "it would have limited interactions with organizations in its immediate environment and direct its attention upward to the parent agency." (Ibid.36)

The agency was at the time of Gummer's study launching a new program function that required the establishment of a functional role for the new program within an existing service network. These circumstances parallel those of the Social Security Administration and the adoption of the SSI program.

Gummer concluded that "an organization's capacity to engage in interorganizational activities will be a function of its location vis a vis its major providers of resources." (Ibid.44) Therefore the organization's orientation can be expected to be vertical (upward to the parent body) and inward (to internal operation), and the causes of poor interorganizational coordination are structural.

If this follows for the Social Security Administration and the SSI program, it would be necessary to alter the structural operations of the Social Security Administration if interorganizational collaboration and coordination were to be successful. The Social Security Administration, at the Federal level, would have to take an active role in directing the use of funds specifically for services relating to other agencies. As it is now, local Social Security District Offices have a high 
degree of autonomy and can, as was seen in Portland during the SSI Alert, choose to operate with an "internal orientation" and thus avoid interagency contacts.

The vertical orientation of the Social Security Administration may account for the lack of incentive as well as the difficulties encountered in attempting to change the focus of the organization. While Armitage (1974) states that horizontal integration would mean clients could get a range of services from one agency, rather than having to go to several agencies with no coordinated efforts, vertical integration/orientation tends to be the predominant theme.

Rosengren (1970) discusses a similar theme in what he calls the "client biography model." He states "the internal structure and dynamics of organizations are closely related to the manner by which organizations intervene in the life course of their clients..." (Rosengren, 1970:120) The theory briefly is that organizations may intervene in the life course of clients along two dimensions: the laterality of focus and the time span of involvement. Laterality may be specific or broad in focus, addressing either a problem of technical change or the whole person. The organization may attach itself to a person's life permanently and follow the person longitudinally, or may intervene only for a short time span in a crisis.

The Social Security Administration has always tended to be nonlateral and longitudinal -- identifying itself with the financial side of individuals until they die. The SSI program added the dimension of laterality -- to look at more than just the financial need of recipients. Stinchcombe (1965) posits the stronger the ties between an old or- 
ganization and the public it serves, the harder it is for the organization to establish a new program function. If this is so, this may explain resistance by the Social Security Administration to become involved with a welfare program.

A nonlateral/longitudinal orientation helps to resolve both internal conflict and external contingencies. If an organization can develop a specific technology around which it can organize a rational and bureaucratic division of labor, the specific and long-termed orientation will be characterized by only exchange involvement at the member level but real commitment at the administrative level. Therefore, the organization can anticipate "efficient but personally detached" work. This has surely been a hallmark of the Social Security Administration.

Hence, because of the type of focus the Social Security Administration has maintained regarding clientele, it was difficult (perhaps impossible) to change midstream and administer a program calling for attention to many needs of the individual. This is a significant finding as other vertically-oriented organizations might be faced with undertaking a similar program change that, too, would not be feasible. This area of organizational change should be investigated further as it deviates from the traditional literature on conflict and coordination.

Gummer (1975) and Armitage's (1974) arguments certainly pose possible answers to why the Social Security Administration has found it hard to become involved in interorganizational relationships due to the implementation of SSI. Perhaps the guidelines for information and referral services are wrong; perhaps the Social Security Administration can yet begin collaboration with the service community to better serve 
the elderly. Further research in this area would be of great interest, particularly if Social Security Administration personnel became the focus for future research. Their views about ideal and actual roles the Social Security Administration plays in the community might lend a broader perspective to understanding the SSI program and its ramifications within a total service strategy for elderly Americans. 


\section{SELECTED BIBLIOGRAPHY}

Armitage, W. A. G. "A Structural View of Welfare Organizations," in Robert W. Klenk and Robert M. Ryan, eds., Practice of Social Work, Belmont, California: Wadsworth Publishing Company, 1974.

Baker, Frank, "An Open-System Approach to the Study of Mental Hospitals in Transition," Community Mental Health Journal, 5, 1969.

Boulding, Kenneth E. "Organization and Conflict," Journal of Conflict Resolution, 1, 1957.

Bureau of Supplemental Security Income, Supplemental Security Income Program, Seattle, Washington: November 1, 1974.

Callison, James C. "Early Experience Under the Supplemental Security Income Program," Social Security Bulletin, 37, June 1974.

Caplow, Theodore, Principles of Organization, New York: Harcourt, Brace and World, 1964.

Cardwe11, James B. "Testimony of Commissioner of Social Security, Department of Health, Education and Welfare, before the United States Special Committee on Aging, Washington, D. C., July $15,1974$.

Center on Social Welfare Policy and Law, NWRO Supplemental Security Income Advocates Handbook, New York: January 1975.

Corwin, Ronald, "Pattern of Organizational Conflict," Administrative Science Quarterly, 14, December 1969.

Crozier, M. The Bureaucratic Phenomenon, London, Tavistock, 1964.

Dutton, John and Richard Walton, "Interdepartmental Conflict and Cooperation: Two Contrasting Studies," Human Organization, 25, Fal1 1966.

"The Management of Interdepartmental Conflict: A Model and Review," Administrative Science Quarterly, 14, March 1969.

Evan, William M. "The Organization-Set: Toward a Theory of Interorganizational Relations," in James D. Thompson and Victor H. Vroom, eds., Organizational Design and Research, Pittsburgh: University of Pittsburgh Press, 1967. 
Goodwin, Leonard and Joseph Tu, "The Social Psychological Bas is for Support of the Social Security System," presented at the Annual Meeting of the American Sociological Association, Montreal, 1974.

Gummer, Burton, "The Interorganizational Relationships of a Public Welfare Agency," Journal of Sociology and Social Welfare, III, September 1975.

Hage, Jerald and Michael Aiken, "Program Change and Organizational Properties, A Comparative Analysis," American Journal of Sociology 72, March 1967.

, "Organizational Interdependence and Intraorganizational Structure," American Sociological Review, 33, December 1968. , "Stages and Strategies: The Problem of the Change Process," in Hage and Aiken, Social Change in Complex Organizations, New York: Random House, 1970.

Harris, Senator Fred R. Statement in Congressional Record, 118, Part 1, Washington, D. C.: U. S. Government Printing Office, January 24, 1972.

Hawley, Amos, Human Ecology: A Theory of Community Structure, New York: New York Press Co., 1950.

Hickson, D. F. "A Convergence in Organization Theory," Administrative Science Quarterly, II, March 1969.

Hollister, Robinson, "Social Mythology and Reform: Income Maintenance for the Aged," The Annals, 415, September 1974.

Janowitz, Morris and William Delaney, "The Bureaucrat and the Public: A Study of Informational Perspectives," American Sociological Quarterly, 2, September 1957.

Jones, Garth N. Planned Organizational Change, New York: Praeger, 1969.

Kennedy, Lenna D., Dorothea Thomas, and Jack Schmulowitz, "Conversions to Supplemental Security Income from State Assistance: A Program Records Study," Social Security Bulletin, 38, June 1975.

Lawrence, Paul R. and Jay W. Lorsch, Organization and Environment, Boston: Division of Reading, Harvard Business School, 1967. , Developing Organizations, Reading: Addison-Wesley, 1969. 
Leavitt, Harold J. "Applied Organizational Change in Industry: Structural, Technological and Humanistic Approaches," in James G. March, ed., Handbook of Organizations, Chicago: Rand-McNally, 1965.

Lebowitz, Barry D. and John L. Dobra, "Income Security for the Elderly," paper presented at 10th International Congress of Gerontology, Jerusalem, June 1975.

Levine, Sol, Paul White and Benjamin Paul, "Community Interorganizational Problems in Providing Medical Care and Social Services," American Journal of Public Health, 53, August 1963.

Litwak, Eugene, "Models of Bureaucracy which Permit Conflict," American Journal of Sociology, 67, September 1961.

Long, Senator H. Statement in Congressional Record, 118, Part 25, Washington D. C.: U. S. Government Printing Office, September 27, 1972.

Mechanic, David, "Organizational Power of Lower Participants," Administrative Science Quarterly, 7, December 1962.

Moynihan, Daniel P. The Politics of a Guaranteed Income, New York: Vintage Books, 1973.

National Senior Citizens Law Center, The. Materials on the Supplemental Security Income Program, Third Edition, Los Angeles: December 1974.

Perrow, Charles, "Organizational Prestige: Some Functions and Dysfunctions," The American Journal of Sociology, 66, January 1961.

Pondy, Louis, "Organizational Conflict: Concepts and Models," Administrative Science Quarterly, 12, September 1967.

Pugh, P. S., D. J. Hickson, C. R. Hinings, K. M. MacDonald, C. Turner and T. Lupton, "A Conceptual Scheme for Organizational Analysis," Administrative Science Quarterly, 8, December 1963.

Rigby, Donald E. "State Supplementation Under Federal SSI Program," Social Security Bulletin, 37, November 1974.

Rosengren, William R. "Structure, Policy, and Style: Strategies of Organizational Control," Administrative Science Quarterly, 12, June 1967.

, "The Careers of $\mathrm{Cl}$ ients and Organizations," in Rosengren and Lefton, eds., Organizations and Clients, Columbus, Ohio:

Merri11, 1970. 
Stinchcombe, Arthur L. "Social Structure and Organizations," in James G. March, ed., Handbook of Organizations, Chicago: RandMcNally, 1965.

Stogdill, Ralph M. "Dimensions of Organization Theory," in James D. Thompson and Victor H. Vroom, eds., Organizational Design and Research, Pittsburgh: University of Pittsburgh Press, 1967.

Stuart, Archibald, "Recipient Views of Cash Versus In-Kind Benefit Programs," Social Service Review, 49, March 1975.

Turk, Herman, "The Establishment of Manpower Poverty Projects and Relations Between Them in Large American Cities," Report for the U. S. Department of Labor, Los Angeles: 1967.

, "Comparative Urban Studies in Interorganizational Relations," Sociological Inquiry, 39, 1969.

, "Interorganizational Networks in Urban Society: Initial Perspectives and Comparative Research," American Sociological Review, 35, February 1970.

U. S. Department of Health, Education and Welfare, Social Security Administration, SSA Service Manual, Washington, D. C.: U. S. Government Printing Office, 1974a.

, SSA Handbook, Fifth Edition, Washington, D. C.: U. S. Government Printing Office, 1974b.

, "Important Information About Your Supplemental Security Income Payments," Washington D. C.: U. S. Government Printing Office, DHEW Publication No. (SSA) 75-11011, December 1974C.

, "A Guide to Supplemental Security Income," Washington D. C.: U. S. Government Printing Office, DHEW Publication No. (SSA) 75-11015, Ju1y 1975a.

SSA Claims Manual, Washington, D. C.: U. S. Government Printing Office, Transmittal Sheet No. 3591, September 1975b.

U. S. Department of Health, Education and Welfare, Social Security Administration, Office of Research and Statistics, Social Security Bulletin, Annual Statistical Supplement, 1973, Washington, D. C.: U. S. Government Printing Office, 1973.

U. S. Senate, Committee on Finance, Social Security Amendments of 1972 , Report to accompany HRT, Washington, D. C.: U. S. Government Printing Office, 1972.

Warren, Roland, The Community in America, Chicago: Rand-McNally, 1963. 
. "The Interorganizational Field as a Focus for Investigation," Administrative Science Quarterly, 12, December 1967.

"The Concerting of Decisions as a Variable in Organizational Interaction," in Roland L. Warren, ed., Truth, Love and Social Change, Chicago: Rand-McNally, 1971.

- The Structure of Urban Reform, Lexington: D. C. Heath, 1974.

White, Paul E. "Intra - and Inter-Organizational Studies,"

Administration and Society, 6, May 1974.

Williams, Walter, "The Supplemental Security Income Program: Potentially the Next Crucial Step Toward Social Security and Welfare Reform," Public Policy Paper No. 5, Institute of Governmental Research, University of Washington, January 1973.

Wright, Charles R. and Herman Turk, "Introductory Comments on the Socialization of Adults," Sociological Inquiry, 37, Winter 1967.

Zald, Mayer N. "The Structure of Society and Social Service Integration," Social Science Quarterly, 50, December 1969. 
$\Lambda \exists \Lambda Y \cap S$ WJISAS $\exists J I \Lambda Y \exists S ~ \Lambda \perp I N \cap W W O J$ ISS

: $\perp W Y O \unlhd M \exists I \wedge Y \exists \perp N I$

\section{$X I O N \exists d d \forall$}




\section{INTERV IEW FORMAT: SSI Community Service System Survey}

Time and Date of Interview:

Interviewer:

General Instructions: read questions in quotes verbatim. "** indicates that question is NOT to be read.

I. GENERAL INFORMATION: (Ask a11)

1. a. Name of $\mathrm{Org} . /$ Agency:

b. Name and position of informant:

2. a. Primary purpose of Org./Agency:

b. Role of informant in Org./Agency operations:

3. a. How long has this $0 \mathrm{rg} . /$ Agnecy been in operations?

And, how long has this 0rg./Agency been providing services for older adults in this community? *(NOTE: If org./Agency is not a direct service provider, ask: "How long has this Org./Agency been operating in its present capacity in this community?")

b. How long has informant been with Org./Agency?

. . . in present position?

4. a. Where does this Org./Agency get its clients? (i.e., outreach, referral) 
b. "Are any of this Org./Agency's activities and/or services for older adults coordinated in any way with the activities and services for older adults sponsored by other organizations"? IF YES, HOW.... (List Below) :

$\ldots$ IF NO, SKIP TO 5 .

PROBE: What Org./Agencies are your activities coordinated with and what activities or services do they provide for you or your clients?

(List primary agencies)

ORGANIZATION/AGENCY

ACTIVITY/SERVICE

2.

3.

4.

5 .

II. ORGANIZATION/AGENCY SERVICES AND STAFF (Ask Administrative Staff ONLY):

5. a. "What kinds of services does (NAME OF ORGANIZATION/AGENCY) provide?"

* INTERVIEWER: Check any that apply* (and go on to b.).

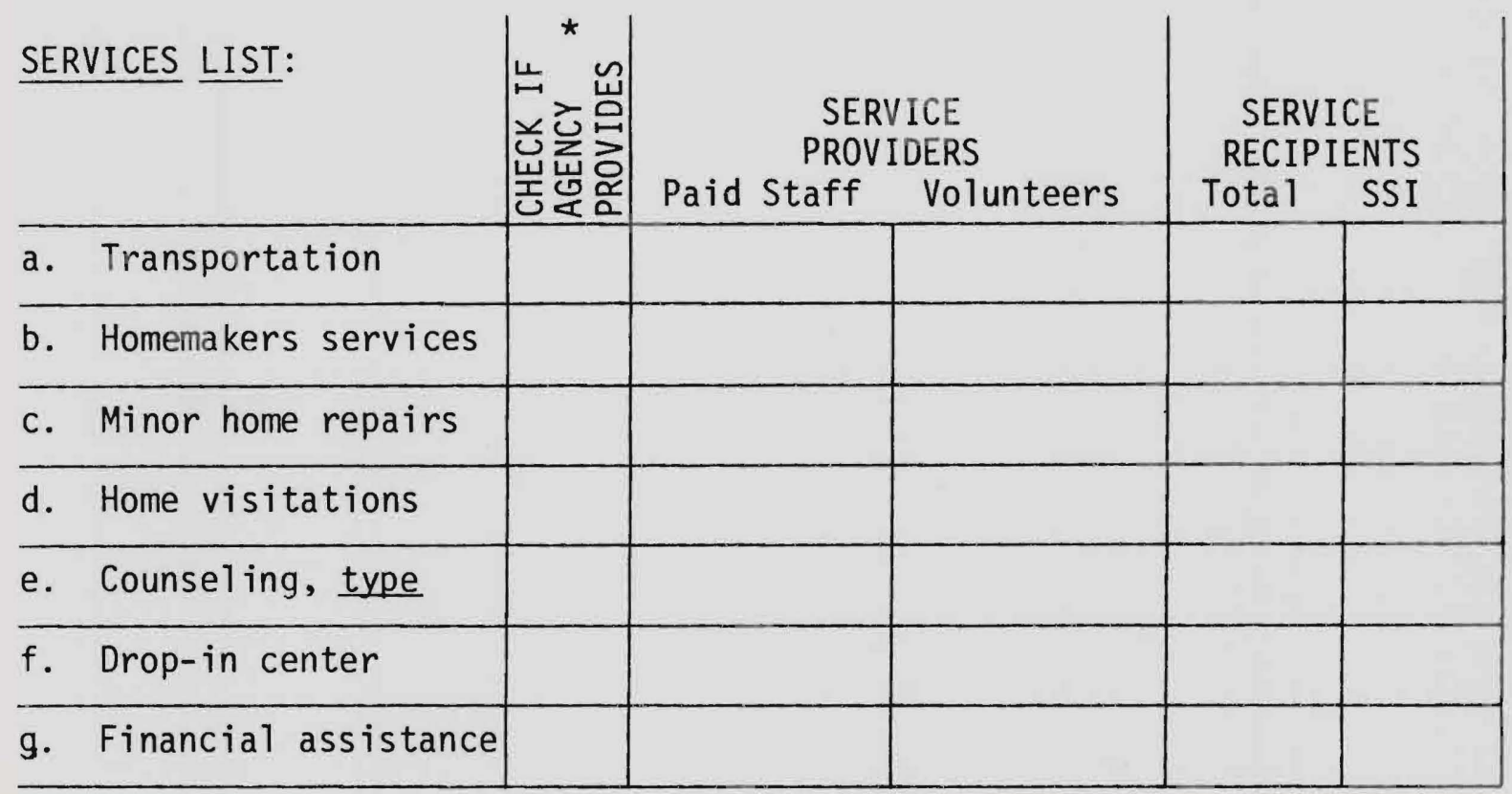




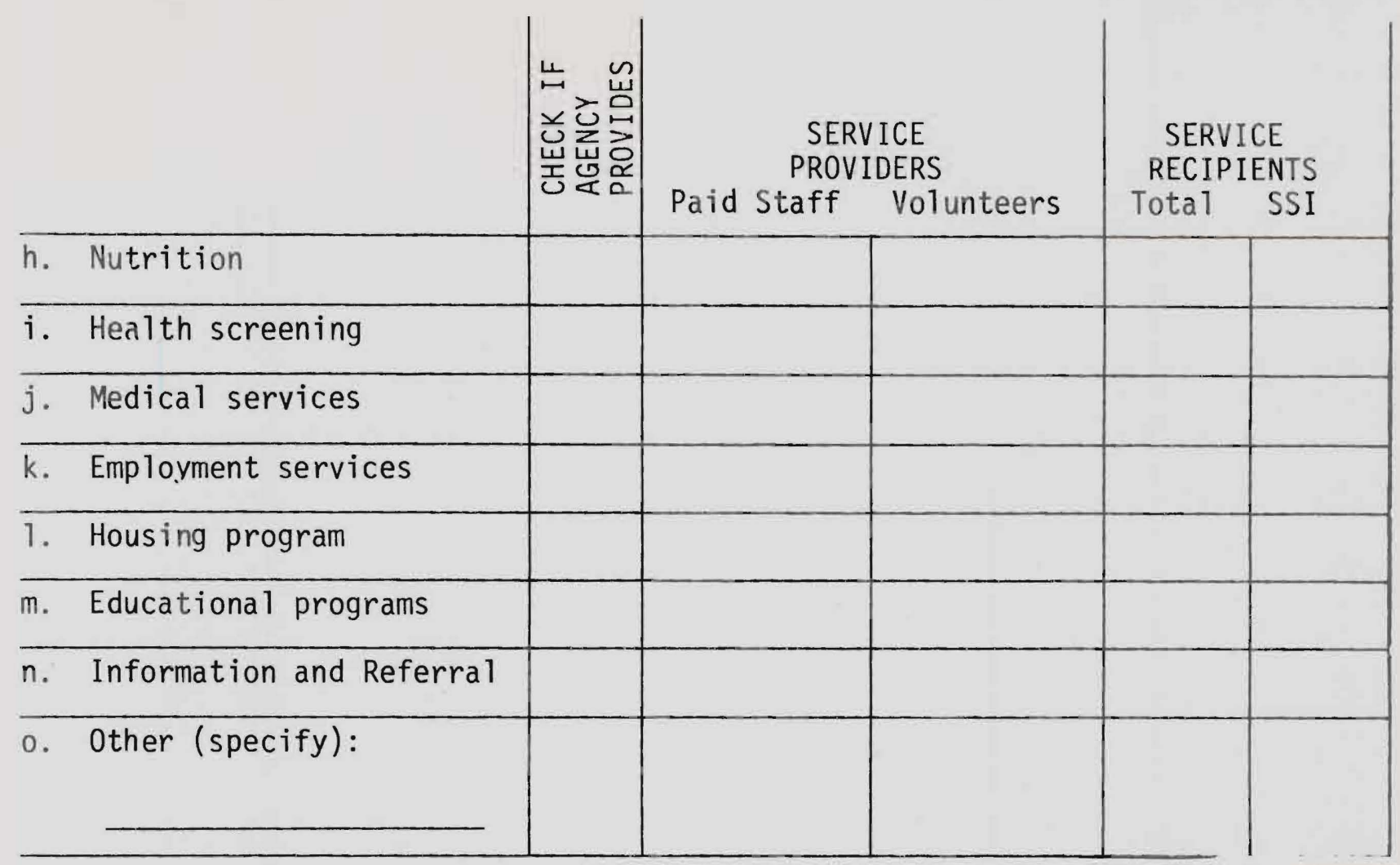

*INTERVIEWER: May lead into this from discussion of staff and clients below.

b. "I wonder if you could tell me something about the size of this org./Agency? By that I mean, HOW MANY PERSONS DOES YOUR AGENCY SERVE? HOW MANY PEOPLE WORK HERE? and, WHAT IS YOUR OPERATING BUDGET"?

PERSONS SERVED:

And of the persons served, how many are older adults?

OLDER ADULTS SERVED?

GENERAL COMMENTS ON ORG./AGENCY SIZE:

STAFF: Number of paid staff:

Number of volunteers:

TOTAL Staff Size: 
ADMINISTRATIVE STAFF: Total: ; Number and Function of each, i.e., (1) Coordinator, (2) Administrators, etc., Paid or Volunteer?

SERVICE STAFF: Total: - Number providing specific services can be entered on SERVICES LIST.) General Comments:

OPERATING BUDGET: \$

PROBE: Does this include matching funds?

FUNDING SOURCE(S):

III. OPERATIONAL DEFINITIONS:

6. a. "The Federal Government has recently implemented a new income maintenance program called "SSI" or Supplemental Security Income. Have you ever heard of this program?" (IF NO, SKIP TO 9.)

(IF YES, ask when and how respondent first heard of SSI.)

b. "By your understanding of what Supplemental Security Income Program is, what is SSI, and how is it administered?" 
7. a. "Have any of the older adults you (your agency) serves tried to get SSI benefits"?

IF NO, SKIP TO 8.

b. PROBE: Have you received any information about SSI problems or procedures from your older clients?

c. "Have you personally ever had to contact the Social Security District Office regarding the SSI program for an older client of yours"? IF YES, what was the result?

IV. INFORMANT'S ATTITUDES ABOUT SSI:

8. "In general, how would you compare the SSI program with the old 01d Age Assistance program run by the Welfare Department"? (Have you noticed any difference?)

PROBE. Do you think SSI gives an older person more prestige or status than $O A A---a r e$ there increased feelings of being a contributing member of society rather than a wlefare recipient?

V. CONTACT WITH SSA:

9. a. "In your role here at (NAME OF ORGANIZATION/AGENCY), do you have contact with the Social Security Administration Office"?

IF NO, SKIP TO 10.

b. How often do you have contact with the Social Security Administration per 
c. Who usually initiaties this contact, your agency or the Social Security Administration?

d. PROBE: Nature of contact, respondent's attitude toward the Social Security Administration, amount of time spent dealing with the Social Security Administration, who contacts whom?

e. How long ago did you begin dealing with the Social Security Administration?

10. "At about the time Supplemental Security Income was implemented in January, 1974, great effort was made to publicize the program. This effort was called the "SSI Alert."

a. "Was your Org./Agency involved in SSI Alert"?

IF YES, what did you do in SSI Alert?

b. "Did the SSI Alert have any effect on your Org./Agency's relations with the Social Security Administration"? IF YES, how?

c. "In genera1, how effective do you think the SSI Alert was in drawing the Social Security Administration into the local social delivery system in this community"? 
11. a. "Have you noticed any change in the frequency and/or purposes of your contacts with the Social Security Administration since Supplemental Security Income was implemented in January, 1974"?

IF YES, PROBE: How has your contact with the Social Security Administration changed?

VI. INFORMANT'S ATTITUDES ABOUT SSA:

12. "Have you ever had occasion to talk with (other) Social Service providers about the role of the Social Security Administration in the local social service delivery system"? . IF NO, SKIP TO 13.

PROBE: What was the nature of the discussion?

13. a. "What role do you see the Social Security Administration playing in providing help to older adults"? (Probe for more than financial but DON'T MENTION"INFORMATION and REFERRAL" ) - might say

1) merely income maintenance?

2) provider of knowledge about services?

3) provider of direct service?

b. "Do you think the Social Security Administration could be doing more to serve older adults in this community"? IF YES, HOW? 
c. "Do you think that the Social Security Administration could (do more to) help your Org./Agency perform its functions"? IF NO, WHY NOT? - IF YES, HOW?

VII. TERMINATION

14. "Is there anything that I haven't asked that you feel is important regarding the impact of Supplemental Security Income or the role of the Social Security Administration in the human service delivery system"?

15. "Does your 0rg./Agency produce any written material about your programs (brochures, annual reports, etc.) that I might read or take with me"?

Any statistical reports regarding the number of clients served, their age, sex, etc., that may be useful for our project? (Interviewers: Get copies if possible; if not perhaps we may be able to review the material at a later date.)

\section{INTERVIEWER NOTE:}

* a. Ask initial administrative contact to identify direct service worker for interview, and specify that the interview will be similar to this one so could he suggest someone you might talk with.

*b. Make appointment with the service worker for interview if respondent is available.

TIME \& DATE OF SCHEDULED APPOINTMENT. 
THANK YOU: "We might like to talk with you (or someone from your organization) again in the future as our project develops," (and thank them for their cooperation and time).

TIME INTERVIEW ENDED: 